\title{
Launching an Accelerated Online MBA Program: Assuring Quality with Scale, Based on Principles of Effective Course Design
}

\author{
Abbas Foroughi \\ University of Southern Indiana \\ Jack Smothers \\ University of Southern Indiana \\ Dinko Bačić \\ University of Southern Indiana \\ Mohammed Khayum \\ University of Southern Indiana
}

\begin{abstract}
This paper describes the challenges and advancements encountered by graduate faculty at a Midwestern public university as it transitioned to offering an accelerated MBA program with online, hybrid, and traditional courses, while experiencing 520\% (from 100 to 620 students) growth over 24 months. Faculty consulted a ten-principle framework of course design to develop new courses for MBA concentrations and adjust teaching methods, assignment structures, student interactions, and teaching assistant integration to deliver a cutting-edge program in a competitive market. Case studies in deploying experiential learning in a fast-paced, large online classroom environment are discussed for three MBA courses.
\end{abstract}

\section{INTRODUCTION}

Since 2011, the Master of Business Administration (MBA) degree has had the most conferrals each year among masters' programs in the U.S. (Byrne, 2014). In addition to the rapid increase in MBA degrees conferred per year, the past decade has witnessed a discernible shift towards online MBAs with shorter durations. In 2018, there were 450 online MBA programs, and new entrants increasingly face the challenge of building awareness, prominence, and affinity with their target market (Online MBA Today, 2018).

Many online MBA programs co-exist with on-campus MBA programs. In most instances, the curriculum and learning goals are the same for online and on-campus versions of the MBA. However, the growth in scale of MBA programs has raised questions about the instructional quality of online delivery. An examination of a random sample of 76 massive open online courses (MOOCs) (Margaryan, Bianco, \& Littlejohn, 2015) found that the majority of MOOCs scored poorly on most instructional design 
principles, and only organization and presentation of course material received higher ratings. Although the Margaryan, Bianco \& Littlejohn (2015) study focused on MOOCs, the results have implications for the design of online MBA courses as well.

This paper examines the launch of an accelerated online MBA program that synthesized contemporary instructional design principles throughout the deployment process (Merrill, 2002, 2009, 2013; Margaryan, Bianco, \& Littlejohn, 2015; Collis, Margaryan, \& Amory, 2005; Frick, Chadha, Watson, \& Zlatkovska, 2010; Gardner, 1999, 2011; Margaryan \& Collis, 2005). Between August, 2016, and August, 2018, the online MBA enrollment at this university grew 520\%, from 100 to 620 students. Due to the rapid enrollment growth, class sizes increased from an average of 65 to 245 for approximately one year before structural adjustments could be made to reduce class sizes.

This paper begins with a description of a ten-principle framework used for effective course development which includes five principles developed by Merrill $(2002,2009,2013)$. These principles were expanded to include five additional principles which were tested and validated by Margaryan, Bianco, \& Littlejohn (2015). Case studies are provided which detail how this framework was consulted and integrated in the development of three courses for the MBA program of interest in this paper.

\section{PRINCIPLES OF EFFECTIVE INSTRUCTION}

The flourishing demand for online MBA programs and the availability of such degrees underscores the importance of developing courses, methods, and materials based on relevant instructional design principles. As pointed out by Phan and Hoover (2014), many online MBA programs are put together haphazardly, without consideration for current instructional theories and principles. The importance of theory-based instructional design was also recognized a few years earlier by David Merrill, who proposed the First Principles of Instruction after extensive examination of contemporary instructional design theories (Merrill, 2002, 2009, 2013). It should be noted that Merrill's work was not specifically focused on online course delivery, but he argued that this set of principles was applicable and valuable in any learning setting.

The instructional design theories studied by Merrill included the Vanderbilt Learning Technology Center's Star Legacy (Schwartz et al., 1999), the 4-Mat model (McCarthy, 1987; McCarthy \& McCarthy, 2006), the instructional episodes model (André, 1986, 1997), the multiple approaches to understanding model (Gardner, 1999), the collaborative problem solving model (Nelson, 1999), constructivist learning environments (Jonassen, 1999), the learning by doing model (Schank et al., 1999), Gagné's categories of learning theory (1985), Van Merriënboer's 4C/ID model (1997), and Reigeluth's Elaboration Theory (1999). Merrill found commonalities among these theories and models that helped to confirm the integrity of his First Principles of Instruction, which include a problem-centered approach, activation of prior knowledge and skills, demonstration of new skills to be developed, and integration of new skill/knowledge into the learner's skill set. The appropriateness and validity of the First Principles of Instruction were further evidenced by a review of 22 current instructional theories (Gardner, 2011).

Using Merrill's (2002, 2009, 2013) First Principles of Instruction, Margaryan, Bianco, \& Littlejohn (2015) examined the design and structure of MOOC courses and added five additional principles gleaned from the instructional design literature (Margaryan \& Collis, 2005) - the development of collective knowledge, learner collaboration, customization of learning activities, real-world resources, and feedback. These additional five criteria were combined with the five First Principles of Instruction to create a tenprinciple framework (See Table 1.), which was validated in more than one hundred online corporate courses to test its ability to measure online course design quality (Margaryan, 2008; Margaryan \& Collis, 2005).

When employed as criteria of effective instruction in the MOOC study, the Ten Principles revealed that except for organization and presentation of course material, the majority of MOOC courses were significantly lacking in all aspects of effective course design and learning environment that were measured (Margaryan, Bianco, \& Littlejohn, 2015). These aspects included using a problem-centered approach, activation of existing experience, demonstration of new skills, opportunities for learners to 
apply their new knowledge or skill to solve problems, facilitation of learner integration of the new knowledge, development of collective knowledge, collaborative learning, support for the learning needs of diverse learners, real-world course materials, and expert feedback to learners.

\section{TABLE 1 \\ TEN PRINCIPLES OF EFFECTIVE COURSE DESIGN}

\begin{tabular}{|c|c|}
\hline \multicolumn{2}{|c|}{ First Principles of Instruction (Merrill, 2002, 2007, 2009, 2013) } \\
\hline Problem-Centered & $\begin{array}{l}\text { Learners acquire skill in the context of finding solutions for real-world } \\
\text { problems that are representative of real-world issues. }\end{array}$ \\
\hline Activation & $\begin{array}{l}\text { Learning is promoted when learners activate existing knowledge and skill, } \\
\text { apply them to new knowledge; and develop new mental models. }\end{array}$ \\
\hline Demonstration & $\begin{array}{l}\text { Learning is promoted when learners observe a demonstration of the skill to be } \\
\text { learned and are shown how to apply new information or skill in new } \\
\text { situations. }\end{array}$ \\
\hline Application & $\begin{array}{l}\text { Learning is promoted when learners apply their newly acquired skill to solve } \\
\text { problems, with scaffolding that is gradually diminished. }\end{array}$ \\
\hline Integration & $\begin{array}{l}\text { Learning is promoted when learners reflect on, discuss, and defend their } \\
\text { newly acquired skill. }\end{array}$ \\
\hline \multicolumn{2}{|c|}{ Five Additional Principles (Margaryan \& Collis, 2005) } \\
\hline $\begin{array}{l}\text { Collective } \\
\text { Knowledge }\end{array}$ & Learning is promoted when learners contribute to the collective knowledge. \\
\hline Collaboration & Learning is promoted when learners collaborate with others. \\
\hline Differentiation & $\begin{array}{l}\text { Learning is promoted when different learners are provided with different } \\
\text { avenues of learning, according to their need. }\end{array}$ \\
\hline Authentic Resources & $\begin{array}{l}\text { Learning is promoted when learning resources are drawn from real-world } \\
\text { settings. }\end{array}$ \\
\hline Feedback & $\begin{array}{l}\text { Learning is promoted when learners are given expert feedback on their } \\
\text { performance. }\end{array}$ \\
\hline
\end{tabular}

\section{Problem-centered}

Learning is promoted when learners acquire skills in the context of real-world problems. Many contemporary learning theories and instructional models such as Constructivism, Authentic Learning, Cognitive Apprenticeship, Situated Learning, Problem-based Learning, and Expansive Learning argue that learning is most effective when learners are engaged in solving problems and building knowledge than when they are presented with information they are required to memorize. In contrast to topiccentered instruction, where a subject is taught in isolation from the real-world tasks, problem-based instruction focuses on working through a progression of interrelated tasks, from the least difficult to the most difficult, that reflect the complexity of real-world settings (Merrill, 2002).

\section{Activation}

Learning is promoted when learners activate existing knowledge and skill as a foundation for new skills. The instructional effectiveness of a course will increase if the course includes learning activities that help learners recall and describe their relevant previous experiences and relate and apply these to what they learn in the course. If learners have not had relevant experience, a course should begin by helping them acquire such experience by, for example, providing real-world or simulated examples that learners can use as a foundation for new learning. However, activation requires more than enabling 
learners to recall or build relevant experience; it also requires learning activities that stimulate the development of mental models and schemes that can help learners incorporate the new knowledge or skill into their existing knowledge (Merrill, 2007).

\section{Demonstration}

Learning is promoted when learners observe a demonstration of the skill to be learned. This principle highlights the importance of showing learners what they could do to apply the new information or skill in new situations rather than merely presenting information about what to do. The effectiveness of a course is enhanced when learners are shown examples of both poor and good practices, when the demonstration is consistent with the type of knowledge or skill being taught, and when learners are guided to relate general information or an organizing structure to specific instances of it (Merrill, 2007).

\section{Application}

Learning is promoted when learners apply their newly acquired skills to solve problems. There is widespread agreement among contemporary learning theories that applying new knowledge or skill to real-world tasks is a necessary condition for effective learning. This principle emphasizes that applying knowledge to a single problem is insufficient for learning and that a course must provide multiple opportunities for learners to apply their new knowledge or skill to a wide range of real-world problems. A key corollary of the application principle is appropriate learner guidance, through diminishing coaching or 'scaffolding'. The basis to this corollary is the observation shared by many learning theories that while in the early stages learners may need considerable support, as learners progress this support is gradually taken away, with more control shifted to the learner to help build their independence. A key mechanism of scaffolding is feedback, and most learning theories have long recognized feedback as the most important form of learner guidance (Merrill, 2002, 2009).

\section{Integration}

Learning is promoted when learners reflect on, discuss, and defend newly acquired skills. Learners have integrated new knowledge and skill into their everyday life when they are able to demonstrate changes in behavior or modification of their existing mental models and are able to defend their new knowledge or skill when challenged. Therefore, the effectiveness of a course is enhanced when, first, learners are provided with opportunities to reflect on what they have learned in order to revise, synthesize, recombine and modify their new knowledge or skills; and, second, when learners are required to demonstrate and defend their new knowledge or skill to peers and others. A meta-review (Merrill, 2002, 2013) indicated that these fundamental principles underpin all contemporary instructional design models and theories.

Several aspects of the above five principles are worth noting. First, they are "relationships that are always taken to be true under appropriate conditions, regardless of program or practice" (Merrill, 2002, 43). Second, they "can be implemented in any delivery system or using any instructional architecture" (Merrill, 2002, 44). Third, "learning from a given program will be promoted in direct proportion to its implementation of these principles" (Merrill, 2002, 44). Fourth, the principles are "design-oriented and prescriptive, rather than learning-oriented or descriptive - they relate to creating learning environments and products rather than describing how learners acquire knowledge and skills" (Merrill, 2002, 44).

\section{Additional Principles of Instructional Design Added to Create the Ten-Principle Framework}

The five items below are the additional principles of instructional design which Margaryan \& Collis (2005) added to the ten-principle framework.

\section{Collective Knowledge}

Learning is promoted when learners contribute to the collective knowledge. The interactive process of collective knowledge construction occurs when a group of individuals creates new knowledge by recombining the contributions of others to form new insights (Lave \& Wenger, 1991). As a result, a group 
of learners as a whole develops and constructs new knowledge, and participants also individually advance and refine their own knowledge (Kimmerle, et al., 2015).

\section{Collaboration}

Learning is promoted when learners collaborate with others. Educators have long recognized the crucial role of dialogue and social interaction in learning (Vygotsky, 1978; Lave \& Wenger, 1991). Collaboration in an online course facilitates the development of critical thinking skills, co-creation of knowledge and meaning, reflection, and transformative learning (Vygotsky, 1978; Lave \& Wenger, 1991).

\section{Differentiation}

Learning is promoted when learners are provided with different avenues of learning, according to their need. Educators and instructional designers must be aware of individual differences, such as cognitive differences and learning styles, prior knowledge, and cultural differences. Learners with low prior knowledge may need more attention and support from instructional designers, while other learners may be able to work independently in web-based learning systems. Adaptability is important to enable a variety of individuals to use the system successfully in learning environments (Alomyan, 2003).

\section{Authentic Resources}

Learning is promoted when learning resources are drawn from real-world settings. Applications of theoretical material in real-life situations make content more relevant and easier to understand. Recent literature on brain function and learning indicates that existing knowledge forms the foundation for incorporating new information into more complex and sophisticated schemas (Theall, 1999; Keller, 2008).

\section{Feedback}

Learning is promoted when learners are given expert feedback on their performance. Feedback must enhance learning, be timely, clearly communicated to students, consistently delivered, and have consistent quality (Black \& William, 1998; Falchikov, 2001; Gibbs \& Simpson, 2004; Hounsell et al, 2007).

\section{IMPLEMENTATION - THREE CASE STUDIES}

With a commitment to developing courses which reflect the best practices of instructional design identified in the ten-principle framework, the administrators and faculty responsible for the online MBA described in this paper consulted the framework to guide the development of courses within the MBA curriculum. The design process and outcomes for three of these courses are described in the follow case studies.

\section{Case Study \#1: CIS 601: Information Systems and Technology Course Description}

CIS601 is the information technology-focused course offered in the MBA Program. This course concentrates on the strategic use of information systems, with emphasis on the Information Systems Strategy Triangle, which relates business strategy with IS strategy and organizational strategy. The underlying theme of this course is that, with information systems at the heart of virtually every business interaction, process, and decision, managers can no longer abdicate participation in decisions regarding their company's use of information systems. Managers must become knowledgeable participants in information system decisions. CIS601 is designed to build the knowledge and skills business managers need to make strategic decisions about information technology, and to introduce them to the use of digital visualizations with software like Tableau. Course topics include the Information systems strategy triangle, strategic use of information resources, organizational strategy and information systems, digital systems and the design of work, information systems and business transformation, architecture and infrastructure, 
security, the business of information technology, governance of the information systems organization, information systems sourcing, managing information technology projects, business intelligence/knowledge management/analytics, and privacy and ethical considerations in information management.

\section{Adaptation of CIS 601 for Online Delivery}

CIS601 had been offered for many years as a face-to-face course, but the growing digital presence of the RCOB's MBA necessitated offering the course online. The course was offered online for a couple of years, serving mostly regional students. All assignments were posted and submitted online. Students were required to take exams on campus, or to arrange for an approved local proctor to administer the exam.

With the move to a totally online MBA, CIS 601 now serves students from across the nation and around the world. Due to rapid enrollment growth, several changes in how the course is run were implemented. First, the MBA Program now utilizes instructional support services such as academic coaches to support the instructor and the students. Depending on course enrollment, faculty determine how many coaches are needed as well as which coaches have the most appropriate background for the particular course. Faculty members provide detailed instructions to the coaches regarding assignments, projects, procedures, and grading rubrics, as well as a table outlining instructor, coach, and student responsibilities. For this eight-week course with an enrollment of 250 students, four coaches were assigned, with each coach being responsible for a portion of the students. The coaches communicate updates, reminders of due dates, and encouraging messages to students. Coaches also grade assignments and projects using guidelines and rubrics provided by the instructor, and in close consultation with the instructor. Throughout the course, when a student has a question about course content that the coaches believe can be better and more thoroughly answered by the instructor, the coaches forward the questions to the instructor.

\section{Consideration of Psycho-Social Factors of Online Learning}

The expanded enrollment has also necessitated consideration of several psycho-social factors related to student learning online that are relevant to large enrollment courses. These factors are widely discussed in the MOOC (massive open online course) literature, and many of them are relevant to large enrollment courses in general. As the following discussion points out, these factors are consistent with the ten criteria for effective instruction based on key instructional design theories and models (Merrill, 2002, 2009, 2013; Margaryan \& Collis, 2005) that were discussed above.

First, research has found that most online learners need to feel "teacher presence" throughout a course in order to feel confident and able to succeed in a course (Garrison \& Anderson, 2003). This factor is addressed in CIS601 by the use of academic coaches, each of whom is assigned a portion of the students to assist, and by the prompt addressing of issues and questions by the instructor, updates and deadline reminders, and other encouraging emails. Prompt, consistent feedback to students (Margaryan \& Collis, 2005) provides scaffolding that supports the learning experience and builds students' confidence in the application of new knowledge (Merrill, 2002, 2009, 2013).

Second, online learners can differ across many dimensions, such as skills (digital and participatory), preferences, learning styles, motivation, engagement, and the context of learning (Terras \& Ramsay, 2014). To the extent possible, an online course should address learner differentiation (Margaryan \& Collis, 2005) and diversity and provide structure that facilitates a high-quality learning experience for diverse learners. CIS601 addresses individual differences in background/experience/preferences by, to the extent possible, giving students choices in project topics. All assignments are problem-centered and require students to analyze and develop solutions to real-world issues (Merrill, 2002, 2009, 2013; Margaryan \& Collis, 2005). A project that focuses on the impact of new IT initiatives includes the choice of either writing about an on-the-job project or about a fictitious IT initiative. A second project, an article review, gives students the choice of a number of different articles from prominent journals, each related to a particular chapter in the text. Students can choose an article, based on interest or relevance to their 
experience, thus underscoring activation, in which students activate existing knowledge and skills as a foundation for new skills.

Third, another aspect of online learning that is relevant to online MBA courses is the finding that discussion and interaction with others are paramount to achieving higher-level learning (Ferschke et al., 2015). This issue is important for MBA students, who, one can assume, are mature and deal with complex, real-world issues daily. Weekly discussion board assignments involve CIS601 students in sharing their opinions and commenting on the postings of other students. This process widens their horizons as they share their own ideas and peruse the experiences and perspectives shared by a diverse group of learners. Students have an opportunity to get to know each other through the first week of the course's discussion board, which requires them to share their educational and work experience, and how they feel information technology fits into their current work and future career goals. These activities involve application of newly acquired skills and the integration of new skills through reflecting on, discussing, and defending newly acquired skills (Merrill, 2002, 2009, 2013).

\section{Case Study \#2: MNGT 611: Leadership Skills and Innovation \\ Course Overview}

Management 611: Leadership Skills and Innovation is an MBA course that addresses leadership in the business context to prepare students for a future of rapid change and increasing complexity. The skills developed in this course include project management, change management, critical thinking, effective decision-making, developing others to improve work engagement, developing business models, conducting a leadership audit, conducting an innovation audit, and the four disciplines of execution. The course has been taught on campus full-term, hybrid full-term, and online full-term, but the most profound learning curve occurred in delivering this broad scope of topics in a large online accelerated (eight-week) term. Teaching a large section of an online MBA course can profoundly impact instructional effectiveness both in the classroom and online because it forces examination of three important course elements: content, design, and feedback.

\section{Course Content}

Most college faculty maintain the intellectual and interpersonal abilities to gain the affection and admiration of their students in the classroom regardless of their teaching skills. However, students taking MBA courses online are primarily concerned with how the content of the course will help them be more effective in their careers. Therefore, the intellectual prowess of the instructor is far less important than the extent to which the topics covered in the course are practical, engaging, and valuable. As a result, these three criteria were the lens through which course topics were selected.

MNGT 611 is in the core of the MBA program so there is great diversity among the students with regard to background, profession, and years of experience. Students do not self-select into the course based on experience or interest, but rather are required to take it for the degree which poses a challenge for faculty teaching courses in the MBA core. In light of this, the selected course topics are broadly applicable across industry segments and levels of career experience. While each topic is not expected to appeal to every student given the population diversity, carefully selecting broadly applicable content is an essential element to appeal to the majority of students.

Once the course topics were identified, the same criteria (i.e., practical, engaging, and valuable) were used for content selection, which was vastly underwhelming as the experiential teaching methodology is nascent relative to the discipline. As a result, custom materials (e.g., readings, simulations, and videos) were curated and/or created to accomplish the course objectives and appeal to the student population. In addition to content, customized presentations, quizzes, and assignments were created for each module. The upfront workload of this approach was high, but the reward paid excellent dividends in student experience and engagement. The results from a survey of 221 students in the online accelerated section of the course indicated that $90.95 \%$ felt the course was very practical, $89.59 \%$ felt it was engaging, and $87.78 \%$ felt it was valuable. Furthermore, $91.39 \%$ indicated that the rigor of the course was very high. Other favorable comments were offered about course quality and impact. 


\section{Course Design}

The format of a course (i.e., online or in-person) should never dictate the learning objectives, but almost always influences the course design. When dealing with large online class sizes, there are several practical course design elements to maintain consistency and improve effectiveness. Practices that were valuable in building a scalable course include: 1) creating grading rubrics in the learning management system (e.g., Blackboard) for each assignment to assist with grading consistency, 2) organizing content into modules rather than task type, 3 ) outlining the module learning objectives on each module folder in the LMS, 4) using thread box via voice thread to facilitate connections and build a sense of community among students, 5) using online video conference office hours via zoom, and 6) organizing module folders consistently (e.g., module instructions and attached documents - module presentation - quiz to assess content coverage - submission folder for assignment documents). While some of these practices apply to all course formats, they become profoundly more important for large online courses. One hundred percent of survey respondents indicated that the LMS site was easy or very easy to navigate and understand the module requirements. Furthermore, while consistency is key in LMS formatting, differentiating assignment types (Merrill, 2002) engages different student strengths and provides diverse pathways for success.

Because online MBA students are keenly sensitive to how their learning will impact their life, course assignments are designed to help them discover how much they need the information before they receive it. For example, when students ran simulations in the course, they first completed a practice run with only instruction on the mechanics of the simulation. In a practice run, students receive credit for participation, thus exposing them to the simulation without the risk of failure and preventing undo stress. Because students take actions without a conceptual framework or an understanding of the theory behind making effective decisions, their performance quickly illustrates their need for knowledge they do not maintain. The subsequent debrief presentation I provide covers content relevant to the simulation and reflection on how that information alters their decisions in the simulation. Students then run the simulation again and typically achieved profoundly better results. This approach is consistent with the problem-centered criterion for effective instruction (Merrill, 2002) as it focuses students' attention on solving the problem at hand, rather than memorizing information for an ambiguous situation they may encounter at some point in their life. This strategy has been more effective than simply telling students why the topics we study are important, since once they are hungry for the information, they place value on it and receive it with excitement.

The application criterion for effective instruction (Merrill, 2002) is built into each module assignment as students apply the content to a scenario in their work-life. This facilitates the transfer of training and makes the material high-touch in a real and experiential way. This reflection/application component highlights the impact the content has on students' lives and helps integrate them as co-creators in the learning process.

This course design was adapted from the scaffolding model which follows an I do - We do - You do approach which helps learners perform a task that would be difficult independently (Gašević, et al., 2015). The scaffolding methodology facilitates experiential learning without overburdening the instructor because students have a frame-of-reference to reflect on when applying the content to themselves or a situation. This approach emphasizes the demonstration component of effective instruction (Merrill, 2002), as examples of unsatisfactory, satisfactory, and excellent performance are presented as well as the assignment instructions and completion process for each assignment.

\section{Course Feedback}

Social presence (i.e., the ability of students to share their personal characteristics and present themselves to others as real people) has been found to relate positively to the ability to construct meaning from course interactions (Lee, 2014). Voice thread boxes were used to elicit social presence as students shared presentations and ideas with peers and received feedback from them. This built a sense of community which helped them feel connected to one another, the university, and the instructor. Students in this course introduced themselves by posting their leadership journey in a thread box which 
accomplished two things: (1) eliciting social presence, and (2) creating student awareness that they have a foundation on which to build with this course material, which aligns with the activation component of effective instruction (Merrill, 2002). Furthermore, the expert feedback (Merrill, 2002) they received from emails and graded assignments enabled them to experience high teacher presence as well. With large sections, clarifying responsibilities of faculty, teaching assistants, and students was also very helpful in conveying teacher presence and eliciting higher-level learning.

Course feedback can even be superior to on-campus sections in some ways. For instance, communication is an essential leadership skill, and presenting to peers provides valuable practice for the learner. Audience feedback during live student presentations is limited by class time, but this constraint does not exist online. Online presentations can be paused, restarted, and watched again so feedback can be deeper and more constructive. Similarly, peer engagement in online discussion boards is often greater than in-class discussions due to higher perceptions of psychological safety, which allows for a freeflowing exchange of ideas. Furthermore, student interactions in this course aligned with the integration component of effective instruction (Merrill, 2002), as students reflected on, discussed, and defended their acquired skills which elicited social presence and provided valuable feedback. While online education may not be ideal for every instructor or learner, selecting content relevant to the student population, using a scalable/appropriate design, and creating feedback interactions which contribute to social and teacher presence are excellent ways to appeal to this segment of learners.

\section{Case Study \#3: CIS 603: Information Visualization \& Dashboarding \\ Course Overview and Challenges}

CIS/BAN603 Business Information Visualization \& Dashboarding is a course offered as part of the Data Analytics track in the online MBA. This new course was implemented in Fall 2017 in seven modules, using Blackboard CMS. The course is designed to develop a vocabulary and framework for discussing, critiquing, and designing visual displays of quantitative data. This entails awareness of human perception and cognition and the use of best practices in the visualization of quantitative data, dashboard design, and telling stories with data.

There were several challenges and potential barriers to successful course deployment. First, the objectives of the course were somewhat optimistic. Second, the course was to be delivered using an eight-week course schedule. There was a real risk that students would not to be able to absorb course materials in such a short timeframe. Third, the course was to be deployed $100 \%$ online, a delivery mode often criticized for student learning effectiveness. Fourth, due to the enrollment size, one academic coach was deemed necessary to support the instructor and the students. The use of an academic coach, while potentially advantageous when dealing with large enrollment, has its own inherent risks, especially if deployed for the first time. Fifth, the course required the use of Business Intelligence (BI) tool (Tableau). Therefore, the course not only needed to ensure the transfer of theoretical knowledge but also to facilitate technology training. Sixth, since the course was new, there were no prior learnings relative to course content difficulty, relevancy, and overall effectiveness. Lastly, the course was developed and taught by a faculty member with no previous experience in $100 \%$ online delivery mode.

\section{Experiential Learning and First Principles of Instruction}

After careful review of course objectives, target student segment, and student segment expectations, a decision was made to deploy the ten-principle framework for Effective Online Course Design (Merrill, 2002, 2009, 2013; Margaryan and Collis, 2005) as an overarching framework and support it through an activities structure based on a modified experiential learning approach (Kwan \& Hew, 2017). Experiential learning is the process of learning through reflection on doing (Kolb, 1984). (See Figure 1.) While the value and need for experiential learning in business programs is noted in higher education (McCarthy \& McCarthy 2006), successful implementation in an online and intensive environment that requires the acquisition of technical skills to allow for 'doing' is rare. Unlike the traditional experiential learning model, which starts with 'concrete experience', in this course, each module began with 'abstract conceptualization' through text and videos that introduced problems and solutions. Multiple texts and 
repetition were used to reinforce concepts and how they work. Students were then asked to 'actively experiment' with a BI tool by following highly customized videos (e.g., Merrill's demonstration principle) that reinforced concepts as students learned how to use the tool. Lastly, the main module assignment provided learners an opportunity to deploy newly acquired concepts and skills in a 'concrete experience,' where students were asked to use the BI tool (Merrill's application principle) in a realistic business problem (Merrill's problem-centered principle). This 'concrete experience' also allowed students to reflect on the experience (Merrill's integration principle), amplifying the 'abstract conceptualization,' thus closing the loop. In the process, students learned the concepts and became proficient in the use of a BI tool. Consequently, the course approach promoted skill acquisition and application in the context of real-world problems that enabled prior knowledge activation and creation of new mental models.

\section{FIGURE 1 \\ EXPERIENTIAL LEARNING MODEL (KOLB, 1984)}

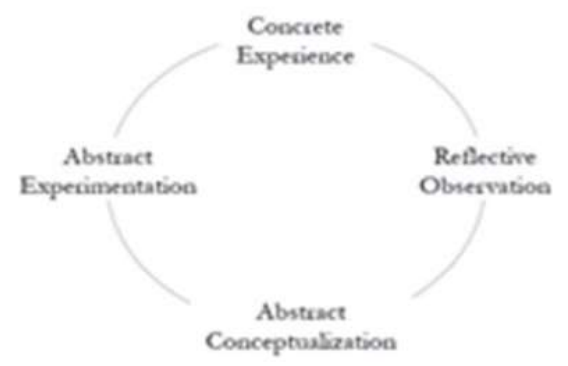

\section{Student-Centric Design}

The experiential learning-focused activities and the overarching tenets in the ten-principle framework were enabled by making student experience and perspective central to course design. The course began with a clear and detailed explanation of why it is relevant to business professionals (Why should I care?). Next, the experiential learning approach was explained to students (Why are you making me do things this way?). The approach included the critical principle of demonstrating data visualization skills to be learned in each module. Demonstration occurred through highly customized and original video content that showed learners how to apply the new information within the concrete BI environment and realistic business context. Furthermore, the demonstration also included examples of ineffective data visualization displays and techniques. Consequently, all readings, videos, and activities were selected through the lens of practicality (Can you make me more effective at work? Now!). Once students understood the course relevancy, pedagogical approach and practical value of the course, concepts were introduced to explain the theoretical underpinnings (Now that I see it working, why is that?).

To ensure trust and confidence in the curriculum content, instructor expertise in this niche course was established (Why this professor?) by leveraging the instructor's journal articles and research lab findings. The instructor created a feedback mechanism after each module (a brief survey) and acted upon the feedback by modifying subsequent modules (Can you show me that you listen to me and that I matter!). All modules were consistent in layout, flow, and expectations (I need to know what to expect!). Each module consisted of trackable 'lecturettes' to allow students to fit the coursework into their busy lives (Make it doable! Am I moving along?). Strategically, at the beginning and the end of each module, an explanation was provided regarding how each module fit into the larger picture (Where was I, and where are we going with this?). Lastly, a purposeful effort was made to signal to the students that the instructor and the coach are available and willing to help (Are you there for me?) by quickly responding to questions, offering virtual office hours, and ad-hoc one-on-one virtual meetings. 


\section{Course Outcomes}

Pre- and post-course surveys provided a way to assess the effectiveness of the outlined course design approach. Students reported spending arouns18 hours per week on the coursework. On a scale from 1(low) - 7 (high), they rated the course 5.6 for difficulty, 6.3 for being engaging, 6.5 for being intensive, and 6.4 for being practical. Despite being intensive, the course withdrawal rate was less than 5\%. Relative to course objectives, students indicated that every course objective was met. Students cited improvements in their perception of course objectives-related abilities ranging from 19 to $92 \%$. When asked how likely they are to recommend the course to their friend or a colleague (on a scale $0-10$ ), students reported the Net Promoter Score of 50 (50 or above is an indicator of an 'excellent' course). Lastly, students offered numerous and mostly very positive comments relative to course evaluation and impact.

In summary, Business Information Visualization \& Dashboarding course implementation faced potential challenges in the fast-paced, large online environment. This case offers theory-based empirical evidence of the ability to mitigate those challenges and foster course effectiveness by deploying the experiential learning model with pedagogical principles that place learners at the center of course design, while integrating principles of effective instructional design: problem-centered, activation, demonstration, activation, and integration (Merrill, 2002, 2009, 2013).

\section{CONCLUSION}

This paper has important implications for practice. The course design framework can help faculty members design better-quality learning experiences and could serve as an evaluation framework. Table 2 indicates the coverage of the ten course design principles in the three courses described in the paper.

TABLE 2

COVERAGE OF THE TEN COURSE DESIGN PRINCIPLES

\begin{tabular}{|l|l|l|l|}
\hline $\begin{array}{l}\text { Course Design } \\
\text { Elements }\end{array}$ & $\begin{array}{l}\text { CIS601 } \\
\text { Information Systems and } \\
\text { Technology }\end{array}$ & $\begin{array}{l}\text { MNGT611 } \\
\text { Leadership Skills and } \\
\text { Innovation }\end{array}$ & $\begin{array}{l}\text { CIS603 } \\
\text { Information Visualization } \\
\text { \& Dashboarding }\end{array}$ \\
\hline $\begin{array}{l}\text { Problem - } \\
\text { Centered }\end{array}$ & $\begin{array}{l}\text { Real-world case analyses } \\
\text { and article reviews }\end{array}$ & $\begin{array}{l}\text { Problems set stage for } \\
\text { material. }\end{array}$ & $\begin{array}{l}\text { Real-world case analyses } \\
\text { and article reviews }\end{array}$ \\
\hline Activation & $\begin{array}{l}\text { Students build on prior } \\
\text { experiences. }\end{array}$ & $\begin{array}{l}\text { Students build on prior } \\
\text { experiences. }\end{array}$ & $\begin{array}{l}\text { Students develop new } \\
\text { mental models, schemes }\end{array}$ \\
\hline Demonstration & $\begin{array}{l}\text { Best practices and real- } \\
\text { world failures analyzed. }\end{array}$ & $\begin{array}{l}\text { Scaffolding clarifies } \\
\text { assignments. }\end{array}$ & $\begin{array}{l}\text { BI tool skills and videos } \\
\text { reinforce concepts }\end{array}$ \\
\hline Application & $\begin{array}{l}\text { Feedback given throughout } \\
\text { the course. }\end{array}$ & $\begin{array}{l}\text { Real-world scenarios and } \\
\text { applied reflections. }\end{array}$ & $\begin{array}{l}\text { New knowledge applied to } \\
\text { real-world problems. }\end{array}$ \\
\hline Integration & $\begin{array}{l}\text { Students demonstrate new } \\
\text { knowledge, understanding. }\end{array}$ & $\begin{array}{l}\text { Learners identify how } \\
\text { they will use new skills. }\end{array}$ & $\begin{array}{l}\text { BI 'concrete experiences' } \\
\text { facilitate new knowledge }\end{array}$ \\
\hline Kollective & $\begin{array}{l}\text { Students learn from each } \\
\text { other in discussion boards. }\end{array}$ & $\begin{array}{l}\text { Voice threads/discussion } \\
\text { boards. }\end{array}$ & $\begin{array}{l}\text { Discussion board builds } \\
\text { collective knowledge. }\end{array}$ \\
\hline Collaboration & $\begin{array}{l}\text { Students critique/learn from } \\
\text { each other. }\end{array}$ & $\begin{array}{l}\text { Voice thread and } \\
\text { discussion boards. }\end{array}$ & $\begin{array}{l}\text { Students critique/learn from } \\
\text { each other. }\end{array}$ \\
\hline Differentiation & $\begin{array}{l}\text { Students are given choices } \\
\text { in assignments. }\end{array}$ & $\begin{array}{l}\text { Assignment types are } \\
\text { differentiated. }\end{array}$ & $\begin{array}{l}\text { Mix of reading, videos, and } \\
\text { hands-on technology. }\end{array}$ \\
\hline $\begin{array}{l}\text { Authentic } \\
\text { Resources }\end{array}$ & $\begin{array}{l}\text { Real-world scenarios are } \\
\text { used exclusively. }\end{array}$ & $\begin{array}{l}\text { Real-world scenarios are } \\
\text { used exclusively. }\end{array}$ & $\begin{array}{l}\text { Real-world scenarios are } \\
\text { used exclusively. }\end{array}$ \\
\hline Feedback & $\begin{array}{l}\text { Coaches, instructor provide } \\
\text { prompt feedback. }\end{array}$ & $\begin{array}{l}\text { Among peers, academic } \\
\text { coaches, and instructor. }\end{array}$ & $\begin{array}{l}\text { Coaches, instructor provide } \\
\text { prompt feedback. }\end{array}$ \\
\hline
\end{tabular}


An area of focus for future research is an examination of the broader design and quality assurance processes and organizational contexts within which online MBAs are developed. Furthermore, research on the rationale, goals, and motivations of administrators and faculty members involved in offering online MBAs should be examined in the situational context of each university. While this study applies existing design frameworks to courses in new modalities, future research should expand on this by examining new frameworks and innovations which deliver cutting edge competencies relevant to today's work environment. A limitation of this study is the lack of consistent quantitative assessment of key course outcomes across the curriculum. While students complete generic course evaluations administered by the university, these evaluations do not address the effectiveness of instruction regarding the learning outcomes which are specific to an individual course. Therefore, a survey tool will be developed and implemented as a means for MBA students to evaluate courses they take, based on the survey used by Margaryan and Collis (2005) and Margaryan (2008). Implementation of both a faculty-conducted evaluation as well as the student survey will enable comparisons of intended coverage of the tenets in the ten-principle framework with actual student perceptions of this coverage.

\section{REFERENCES}

Alomyan, H. (2003) Individual differences: Implications for web-based learning design. International Education Journal 4(4). Educational Research Conference 2003 Special Issue, 188-196.

André, T. (1986). Problem solving in education. In G. D. Phye and T. Andréé (Eds.), Cognitive Classroom Learning: Understanding, Thinking, And Problem Solving (pp. 169-204). San Diego, CA: Academic Press.

André, T. (1997). Selected microinstructional methods to facilitate knowledge construction: implications for instructional design. In R.D. Tennyson, F. Schott, N. Seel, \& S. Dijkstra (Eds.), Instructional Design: International Perspective: Theory, Research and Models. Vol. 1 (pp. 243-267). Mahwah, NJ: Lawrence Erlbaum Associates.

Black, P., \& William, D. (1998). Assessment and classroom learning. Assessment in Education, 5(1), 7-74.

Byrne, J. A. (2014). Why the mba has become the most popular master's degree in the U.S. Fortune.com, May 31. http://fortune.com/2014/05/31/mba-popular-masters-degree/

Collis, B., Margaryan, A., \& Amory, M. (2005). Multiple perspectives on blended learning design. Journal of Learning Design, 1(1), 12-21.

Falchikov, N. (2001). Learning Together: Peer Tutoring in Higher Education. London: RoutledgeFalmer.

Ferschke, O., Howley, I., Tomar, G., Yang, D., \& Rosé, C.P (2015) Fostering discussion across communication media in massive open online courses. Proceedings of the 11th, International Conference on Computer Supported Collaborative Learning, Gothenburg, Sweden, 459-466.

Frick, T., Chadha, R., Watson, C., \& Zlatkovska, E. (2010). Improving course evaluations to improve instruction and complex learning in higher education. Educational Technology Research and Development, 58, 115-136.

Gagné, R. M. (1985). The Conditions of Learning and Theory of Instruction, 4th ed. New York: Holt, Rinehart and Winston.

Gardner, H. (2011). How award-winning professors in higher education use Merrill's first principles of instruction. International Journal of Instructional Technology and Distance Learning, 8(5), 3-16.

Gardner, H. (1999). Multiple approaches to understanding. In C.M. Reigeluth (Ed.), Instructional-Design Theories and Models: A New Paradigm of Instructional Theory, Vol.2. Mahwah, NJ: Lawrence Erlbaum Associates.

Garrison, D. R., \& Anderson, T. (2003). E-Learning in the 21st Century. Abingdon, UK \& NewYork: Routledge Falmer.

Gašević, D., Adesope, O., Joksimović, S., \& Kovanović, V. (2015). Externally-facilitated regulation scaffolding and role assignment to develop cognitive presence in asynchronous online discussions. The Internet and Higher Education, 24, 53-65. 
Gibbs, G., \& Simpson, C. (2004). Conditions under which assessment supports students' learning. Learning and Teaching in Higher Education, 1, 3-31.

Harasim, L. (2012). Learning Theory and Online Technologies. New York, NY: Routledge Press. Jonassen, D. (1999) Designing constructivist learning environments, in Charles M. Reigeluth (Ed.), Instructional Design Theories and Models, Vol. 2 (pp. 215-239). Mahwah, NJ: Lawrence Erlbaum Associates, Inc., Pub.

Keller, J. M. (2008). An integrative theory of motivation, volition, and performance. Technical Instruction, Cognition, and Learning, 6(2), 79-104.

Kimmerle, J., Moskaliuk, J., Oeberst, A., \& Cress, U. (2015). Learning and collective knowledge construction with social media: a process-oriented perspective. Educational Psychologist, 50(2), $120-137$.

Kolb, D (1984). Experiential Learning as the Source of Learning and Development. Englewood Cliffs, NJ: Prentice Hall.

Kwan, C., \& Hew, K.F. (2017) A critical review of flipped classroom challenges in k-12 education: Possible solutions and recommendations for future research. Research and Practice in Technology Enhanced Learning, 12(1).

Lave, J., \& Wenger, E. (1991). Situated learning: legitimate peripheral participation. Cambridge: Cambridge University Press.

Lee, S. M. (2014). The relationships between higher order thinking skills, cognitive density, and social presence in online learning. The Internet and Higher Education, 21, 41-52.

Margaryan, A. (2008). Work-Based Learning: A Blend of Pedagogy and Technology. Saarbruecken: AV Akademikerverlag.

Margaryan, A., Bianco, B., \& Littlejohn, A. (2015). Instructional quality of massive open online courses (MOOCs). Computers \& Education, 80, 77-83.

Margaryan, A., \& Collis, B. (2005). Design criteria for work-based learning: Merrill's first principles of instruction expanded. British Journal of Educational Technology, 36(5), 725-738.

McCarthy, P. R., \& McCarthy, H. M. (2006). When case studies are not enough: Integrating experiential learning into business curricula. Journal of Education for Business, 81(4), 201-204.

McCarthy, B. (1987). The 4MAT System: Teaching to Learning Styles with Right/Left Mode Techniques. Barrington, Ill.: Excel, Inc.

Merrill, M. D. (2002). First principles of instruction. Educational Technology Research and Development, 50(3), 43-59.

Merrill, M. D. (2007). First principles of instruction: a synthesis. Trends and Issues in Instructional Design and Technology, 2nd Edition. R. A. Reiser and J. V. Dempsey. Upper Saddle River, NJ, Merrill/Prentice Hall. 2: 62-71.

Merrill, M. D. (2009). First principles of instruction. In C. M. Reigeluth, \& A. Carr (Eds.), Instructional Design Theories and Models: Building a Common Knowledge Base, Vol. 3 (pp. 3-26). New York: Routledge/Taylor and Francis.

Merrill, M. D. (2013). First Principles of Instruction: Identifying and Designing Effective, Efficient and Engaging Instruction. Hoboken, NJ: Pfeiffer/John Wiley \& Sons.

Nelson, L. M. (1999). Collaborative problem solving. In C. M. Reigeluth (Ed.), Instructional Design Theories and Models: A New Paradigm of Instructional Theory (pp. 241-267). Mahwah, NJ: Lawrence Erlbaum Associates, Inc.

Online MBA Today. https://www.onlinembatoday.com/rankings/best-value-online-mba/ (accessed June 5,2018 ).

Phan, V., \& Hoover, J. D. (2014) The distance mba: A need for guiding philosophy and theories. Developments in Business Simulation and Experiential Learning, 41, 361-370.

Reigeluth, C.M. (1999). The elaboration theory: Guidance for scope and sequence decisions. In C.M. Reigeluth (Ed.), Instructional-Design Theories and Models: A New Paradigm of Instructional Theory, Vol. 2 (pp. 425-453). Hillsdale, NJ: Lawrence Erlbaum Assoc. 
Schank, R.C., Berman, T.R., \& Macpherson, K.A. (1999). Learning by doing. In C.M. Reigeluth (Ed.) Instructional Design Theories and Models: A New Paradigm of Instructional Theory, 2, 161181. Mahwah, NJ: Lawrence Erlbaum Associates

Schwartz D., Lin, X., Brophy, S., \& Bransford, J.D. (1999). Toward the development of flexibly adaptive instructional designs. In C.M. Reigeluth (Ed), Instructional Design Theories and Models: A New Paradigm of Instructional Theory, 2, 183-213. Mahwah, NJ: Lawrence Erlbaum Associates.

Terras. M.M., \& Ramsay, J. (2014) Psychological perspective on the temporal dimensions of e-learning. E-Learning and Digital Media 11(2), Special Issue: The Temporal Dimensions of E-learning, $108-122$.

Theall, M. (1999). What have we learned? A synthesis and some guidelines for effective motivation in higher education. In M. Theall (Ed.), Motivation from Within: Approaches for Encouraging Faculty and Students to Excel: New Directions For Teaching and Learning, 78. San Francisco: Jossey Bass.

van Merriënboer, J.J.G. (1997). Training Complex Cognitive Skills. Englewood Cliffs: Educational Technology Publications.

Vygotsky, L. S. (1978). Mind in Society: The Development of Higher Psychological Processes. Cambridge, MA: Harvard University Press. 